\title{
Economics of Milk Production and Marketing in Thoubal District of Manipur, India
}

\author{
O. Krishnadas Singh*, Y. Chakrabarty Singh, \\ Kh. Rishikanta Singh and N. Okendro Singh
}

College of Agriculture, Central Agricultural University, Imphal-795004, Manipur, India

*Corresponding author

\section{Keywords}

Cost and return, Marketing efficiency, Price spread, Producers' share and problems

Article Info

Accepted:

12 May 2019

Available Online:

10 June 2019

\section{A B S T R A C T}

The study was conducted in Thoubal district of Manipur state with the overall objectives of the cost and return analysis, resource use efficiency, marketing efficiency and its problems during production and marketing. The research is based on the data collected by using proportionate sampling from a total of 100 dairy farm sample households comprising of 60 Crossbred and 40 Local cows. Net maintenance cost for a milking crossbred cow was Rs. 161.71 and for a milking local cow was Rs. 55.42 per day, respectively. Net return per day from a crossbred milking cow was Rs. 166.04 while for a local milking cow was Rs. 24.58. So, a crossbred milking cow was economical more than the local cow. MVP and MFC ratios for green fodder and labour were 4.45 and 2.32, respectively for crossbred cow. MVP and MFC ratios for green fodder and concentrate were 6.73 and 2.96, respectively for local cow. Other variables in the entire farm are non-significant. Marketing efficiency of milk was estimated by analyzing price spread of different marketing channels. For crossbred cows the producer's share in consumer's rupee was highest 98.70 percent in channel-III, (Producer $\rightarrow$ Consumer) as there were no intermediaries involve in the channel. In channel-I (Producer $\rightarrow$ Collector $\rightarrow$ Cooperative $\rightarrow$ Retailer $\rightarrow$ Consumer and channel-II (Producer $\rightarrow$ Retailer $\rightarrow$ Consumer) the producer's share in the consumer's rupees were at 60 percent and 85 percent, respectively. For local cows, the farmers only marketed through channel-III and producer's share was found 98.77 percent. The major problems faced by the respondent farmers during production were high price of concentrate, low availability of green and dry fodders and lack of veterinary facilities. The major problems in marketing were delay in payment by unorganized sector, low price of liquid milk, lack of market information and lack of regulated market and milk cooperative.

\section{Introduction}

In agriculture sector, dairying has been one of the fastest growing enterprises. In our country, it is the backbone of economy for many small farmers and landless labourers. It is a complementary and supplementary enterprise to crop farming. According to the interim reports of the National Commission on Agriculture, dairying has recognized as an enterprise that can supplement the income and reduce unemployment of the rural areas. So, 
dairy farming being a labour intensive in nature has been recognized as an important subsidiary enterprise to inflate the income and employment of small farmers, marginal farmers and landless labourers in rural areas. The growth of Indian diary industry during the last four decades has been impressive, with the launching of Operation Flood in 1970 and other dairy development programs. India has becoming the highest milk producer country in the entire globe. The estimated milk production was around 80.6 million tonnes in 2000-2001 and 121.8 million tonnes in 2010-2011 which shows an increase of 4.22 percent over the past ten years. This is because of two reason, firstly introduction of efficient milk production pattern associated with agriculture and secondly involvement of milk producers at various levels of procuring, processing and marketing through cooperatives. Among the states of north-east India, Manipur is also one of the largest milk producing state. According to the source of $19^{\text {th }}$ Quinquennial livestock census, 2012, cattle population was 263.84 (in '000) which constitute 44.31(in '000) crossbred, 219.53 (in '000) local breeds and the population of buffaloes was 66.37 (in '000). The total production of milk of the state was estimated 81.77 litres (in '000) during 2015-16. However, the availability per capita of milk was 33 gm per day which is very low as compared to the India Council of Medical Research (ICMR) recommendation (250 gm/day).

\section{Materials and Methods}

The study was conducted in Thoubal district of Manipur using proportionate sampling method for the selection of following steps. Two blocks were selected purposively for the study. From the two blocks, four villages were selected purposively and 100 household farmers consisting of 60 crossbred cow farmers and 40 local cow farmers were selected randomly from those four villages. The study was predominantly based on primary data collected through personal interview method using a structured developed pre-tested schedule. The data collected detailed information on household characteristics, infrastructural conditions of the farmers, details of the inputs and outputs in milk production, transaction costs, marketing channels, marketing efficiency and problems faced during production and marketing. The collected data were analyzed by using appropriate statistical tools, formulas, ratios, percentages etc.to derived the results which are presented using graphical and tabular means.

\section{Results and Discussions}

Related with the objectives of the research, the findings for the present analysis "Economics of milk production and marketing in Thoubal district of Manipur" are given below.

Table 1 shows that the overall daily average maintenance gross cost per milking cow was found to be Rs. 111.96. Of the total gross cost, total variable cost constituted Rs. 101.79 (90.91\%) and the rest Rs. 10.17 (9.08\%) consisted of total fixed cost. Then, the maintenance cost per milking crossbred cow was Rs.165.81 while for local cow it was Rs. 58.15, respectively. The overall Gross return per milking cow was Rs. 203.87 for overall categories which comprised of Rs. 327.75 and Rs. 80 for crossbred and local cow, respectively. Whereas the overall net return per day per milking cow was Rs. 95.32 which was highest for crossbred cow i.e. Rs. 166.04 and local cow was Rs. 24.58, which indicated that crossbred cow category of farmers have more yield and profits then local cow. The overall farm business income was Rs. 91.91 which comprised of Rs. 161.94 for crossbred and Rs. 21.85 for local cows, respectively. 
The overall per litre cost of milk was Rs. 19.55 which was Rs. 17.02 for crossbred and Rs. 34.63 for local cow farm category. Again, the overall per litre return of milk production was found to be Rs. 16.56 which was Rs. 17.04 for crossbred and Rs. 13.65 for local cow category. Overall benefit cost ratio was 1.82 which was 1.97 and 1.37 for crossbred and local cow, respectively. Table 2 shows that overall per milch cow daily gross cost was Rs. 94.51 while the corresponding cost for crossbred was Rs. 143.46 for crossbred and for local cow it was Rs. 45.60. The overall gross return was Rs. 170.69 which was Rs 251.16 for crossbred and Rs. 40 for local cow. The per milch local cow net returns was found negative i.e Rs. -2.87 and for crossbred cow were positive Rs. 111.80, which shows that crossbred farm category have more profit and operate efficiently. Again, per milch cow overall net return was Rs. 79.59 per day. The farm business overall income was Rs. 76.59 which comprised Rs. 107.7 for crossbred and Rs. -5.6 for local cow, respectively. The overall per litre milk production cost was Rs. 22.54 which was Rs. 19.14 and Rs. 53.58 for crossbred and local cow, respectively. The overall return per litre milk production was found Rs. 18.85 which was Rs. 14.79 and Rs. -7 for crossbred and local cow, respectively. The benefit cost ratio for overall was 1.80 which was 1.75 and 0.87 for crossbred and local cow, respectively.

An analysis of the Table 3 shows that regression coefficient of expenditure for crossbred cows on green fodder and labour were found positive and significant at 1 percent with total explained variation i.e. $\mathrm{R}^{2}$ as 0.56 percent. For local cows concentrate and green fodder were found positive and significant at 1 percent and 5 percent with total explained variation i.e. 0.83 percent. The Cobb-Douglas production function analysis for crossbred cows revealed that milk productivity could be increase through feeding green fodder and giving more extra labour economically and for local cows, production could increase through green fodder feeding and concentrate. The table again shows that for the crossbred cow regression coefficients for expenditure on concentrate was found positive but insignificant and veterinary and dry fodder was found negative. Hence, the productivity could only be improved in the study area through green fodder feeding and giving more labour efficiently.

An analysis of the Table 4 shows that the marginal value product and marginal factor cost ratios of green fodder and labour were 4.45 and 2.32 in crossbred cow was positive and significant. It thus shows that green fodder and labour was under utilized in the area of study. The green fodder and labour used can further be increased to obtain a higher return. For local cow, the marginal value product from unit cost ratios are 6.73 and 2.96 for green fodder and concentrate was found to be positive and significant, which shows that they were used efficiently in both category farms and can further increased. Other variables like dry fodder and veterinary were not calculated as they were found to be non-significant.

The technical efficiency of milk production is presented in Table 5. The crossbred farmers had a mean technical efficiency level of 90.25 percent that shows around 9.75 level of increases in output without additional resources. From the table it can be noted that about 38.33 percent of the respondent farmers were operating at 86-88 percent efficiency that indicates milk production can be increased by 12.5 percent without any additional resources. Around 33.3 percent of the respondent farmers were operating at 8385 percent efficiency level that indicates a scope for improvement of milk production by 13.6 percent. Again 16.66 percent of the 
sample farmers were operating at 80-82 percent efficiency which shows there is a wider scope for increasing the output level by 17.5 percent and 11.66 percent of the respondent farmers were operating at 91-93 percent which shows 7.5 percent of milk production can be increased without any additional resources.

Likewise, the local cow farmers had also a mean technical efficiency level of 89.90 percent that shows around 11.10 percent level of increases in output without additional resources. About 42.5 percent of the respondent farmers were operating at $86-88$ percent efficiency that indicates milk production can be increased by 13.5 percent without any additional resources. Around 27.5 percent of the respondent farmers were operating at 80-82 percent efficiency level that indicates a scope for improvement of milk production by 18.4 percent. Again 20 percent of the sample farmers were operating at 83.85 percent efficiency which shows there is a wider scope for increasing the output level by 14.5 percent and 10 percent of the respondent farmers were operating at 91-93 percent which shows 8.5 percent of milk production can be increased without any additional resources.

The price spread of milk marketed in Thoubal market through different channels of trade for crossbred cow was presented in Table 6. The producers, who sold their produce through channel- I, channel -II and channel- III received Rs. 30, Rs. 34 and Rs. 39.48 per litre, respectively. The overall marketing cost gave by the producer and middlemen were found 6 percent, 2.5 percent and 1.3 percent of consumers' rupee in case of channel-I, channel -II and channel- III, respectively. Marketing margin incurred per litre by the producers was highest in channel-I 34.00 percent than channel-II 12.5 per cent. Price paid by the consumer for channel-I was Rs.
50, for channel-II was Rs.40 and for channelIII was Rs. 40. Price spread for channel-I was Rs. 20, for channel-II was Rs.15 and for channel-III was Rs.0.52. Higher the value of price spread lower the marketing efficiency and lower the value of price spread higher the marketing efficiency. Hence, it was understand from the table that category-III can be considered as the most efficient among the different channels for sale of milk.

Table 7 shows the price spread of milk for local cow through channel-III. For local cow, the milk was marketed only through this channel. The producer selling price was Rs. 50 , net price received by the farmers was Rs. 49.45, marketing cost was Rs. 0.55 , price paid by the consumer was Rs. 50 and price spread was Rs. 0.55.

In Table 8 the producer share on consumer rupee for the marketing milk for crossbred cow through different channels of trade is presented. The study of the table revealed that the producers' share on consumer rupees was highest in channel-III 98.70 per cent followed by channel-II and channel- I which comprises of 85.00 per cent and 60.00 per cent respectively. The producer farmer, who sold their produce through channel-I, channel-II and channel- III received Rs.30, Rs.34 and Rs.39.48 per litre respectively. The retail prices paid by the consumer were found Rs. 50, Rs. 40 and Rs.40 of channel-I, channel-II and channel-III, respectively. Therefore, from the table it was clear that category-III can be considered to be the most efficient among the different channel for sale of milk.

The analysis of the below Table 9 shows that the producers' share in consumer rupees for the local cow has only one channel that was channel-III 98.77 percent. The farmer, who sold their produce through channel- III received Rs. 49.45 per litre. The retail price the consumer paid was Rs.50 for channel-III. 
Table.1 Maintenance cost and return per milking cow per day

\begin{tabular}{|c|c|c|c|}
\hline Particulars & \multicolumn{3}{|c|}{ Farm category } \\
\hline A. Variable Cost & Crossbred Cow & Local Cow & Overall \\
\hline Dry fodder & $11.33(6.83)$ & $9.5(16.33)$ & $10.41(9.29)$ \\
\hline Green fodder & $42.65(25.75)$ & $13.12(22.56)$ & $27.88(24.90)$ \\
\hline Concentrate feed & $68.05(41.04)$ & $14.96(24.96)$ & $41.28(36.87)$ \\
\hline Total feed cost & $122.03(73.59)$ & $37.14(63.86)$ & 79.58(71.07) \\
\hline Human labour & $20.66(12.46)$ & $12.71(21.85)$ & $16.68(14.89)$ \\
\hline Veterinary \& Medicine & $5.86(3.53)$ & $0.95(1.63)$ & $3.40(3.03)$ \\
\hline Miscellaneous & $3.66(2.20)$ & $0.60(1.03)$ & $2.13(1.90)$ \\
\hline Total Variable Cost(TVC) & $152.21(91.79)$ & $51.40(88.39)$ & $101.79(90.91)$ \\
\hline \multicolumn{4}{|l|}{ B. Fixed Cost } \\
\hline Depreciation & $6.84(4.12)$ & $4.10(7.05)$ & $5.47(4.88)$ \\
\hline Interest on fixed capital & $6.76(4.07)$ & $2.65(4.55)$ & $4.70(4.19)$ \\
\hline Total Fixed Cost (TFC) & $13.60(8.20)$ & $6.75(11.60)$ & $10.17(9.08)$ \\
\hline Gross cost $(\mathrm{TVC}+\mathrm{TFC})=\mathrm{A}$ & $165.81(100)$ & $58.15(100)$ & $111.96(100)$ \\
\hline Value of cow dung $=B$ & 4.10 & 2.73 & 3.41 \\
\hline Net cost $(A-B)=C$ & 161.71 & 55.42 & 108.55 \\
\hline Avg. price per litre of milk & 34.50 & 50 & 42.25 \\
\hline $\begin{array}{l}\text { Avg. milk } \\
\text { prod./animal/day(lit.) }\end{array}$ & 9.50 & 1.60 & 5.55 \\
\hline Gross return $=\mathrm{D}$ & 327.75 & 80 & 203.87 \\
\hline Net return $=(D-C)$ & 166.04 & 24.58 & 95.32 \\
\hline Farm business income $=(D-A)$ & 161.94 & 21.85 & 91.91 \\
\hline Cost/litre of milk(Rs.) & 17.02 & 34.63 & 19.55 \\
\hline Return /litre of milk(Rs.) & 17.04 & 13.65 & 16.56 \\
\hline Benefit Cost ratio(D/A) & 1.97 & 1.37 & 1.82 \\
\hline
\end{tabular}


Table.2 Maintenance cost and return per milch cow per day

\begin{tabular}{|l|c|c|c|}
\hline Particulars & \multicolumn{3}{|c|}{ Farm category } \\
\hline A. Variable Cost & Crossbred Cow & Local Cow & Overall \\
\hline Dry fodder & $9.17(6.39)$ & $5.2(11.40)$ & $10.41(9.29)$ \\
\hline Green fodder & $36.31(25.31)$ & $9.39(20.59)$ & $27.88(24.90)$ \\
\hline Concentrate feed & $54.20(37.78)$ & $10.00(21.92)$ & $41.28(36.87)$ \\
\hline Total feed cost & $\mathbf{9 9 . 6 8 ( 6 9 . 4 8 )}$ & $\mathbf{2 4 . 5 9 ( 5 3 . 9 2 )}$ & $\mathbf{7 9 . 5 8}(\mathbf{7 1 . 0 7})$ \\
\hline Human labour & $20.66(14.40)$ & $12.71(27.87)$ & $16.68(14.89)$ \\
\hline Veterinary \& Medicine & $5.86(4.08)$ & $0.95(2.08)$ & $3.40(3.03)$ \\
\hline Miscellaneous & $3.66(2.55)$ & $0.60(1.31)$ & $2.13(1.90)$ \\
\hline Total Variable Cost(TVC) & $\mathbf{1 5 2 . 2 1}(\mathbf{9 1 . 7 9 )}$ & $\mathbf{3 8 . 8 5 ( 8 5 . 1 9 )}$ & $\mathbf{1 0 1 . 7 9 ( 9 0 . 9 1 )}$ \\
\hline B. Fixed Cost & & & \\
\hline Depreciation & $6.84(4.76)$ & $4.10(8.99)$ & $5.47(4.88)$ \\
\hline Interest on fixed capital & $6.76(4.64)$ & $2.65(5.81)$ & $4.70(4.19)$ \\
\hline Total Fixed Cost (TFC) & $\mathbf{1 3 . 6 0 ( 9 . 4 7 )}$ & $\mathbf{6 . 7 5}(\mathbf{1 4 . 8 0})$ & $\mathbf{1 0 . 1 7}(\mathbf{9 . 0 8})$ \\
\hline Gross cost (TVC+TFC)=A & $143.46(100)$ & $45.60(100)$ & $111.96(100)$ \\
\hline Value of cow dung=B (1) & 4.10 & 2.73 & 3.41 \\
\hline Net cost (A-B)=C & 139.36 & 42.87 & 108.55 \\
\hline Avg. price per litre of milk & 34.50 & 50 & 42.25 \\
\hline $\begin{array}{l}\text { Avg. milk } \\
\text { prod./animal/day(lit.) }\end{array}$ & 7.28 & 0.80 & 5.55 \\
\hline Gross return=D & & & \\
\hline Net return=(D-C) & 251.16 & 40 & 203.87 \\
\hline Farm business income=(D-A) & 111.80 & -2.87 & 95.32 \\
\hline Cost/litre of milk(Rs.) & 107.7 & -5.6 & 91.91 \\
\hline Return /litre of milk(Rs.) & 19.71 & 57.00 & 23.39 \\
\hline Benefit Cost ratio(D/A) & 14.79 & -7.00 & 18.85 \\
\hline & 1.75 & 0.87 & 1.80 \\
\hline
\end{tabular}

Table.3 Estimates of parameters of Cobb- Douglas milk production function of sample farms

\begin{tabular}{|c|c|c|c|c|c|c|c|c|c|}
\hline \multirow[b]{2}{*}{$\begin{array}{c}\text { Farm } \\
\text { Category }\end{array}$} & \multirow[b]{2}{*}{$\begin{array}{c}\text { No. of } \\
\text { observatio } \\
\text { n }\end{array}$} & \multirow[b]{2}{*}{$\begin{array}{c}\text { Constan } \\
t\end{array}$} & \multicolumn{7}{|c|}{ Estimated parameters } \\
\hline & & & $\begin{array}{c}\text { Dry } \\
\text { Fodder } \\
\left(\mathrm{x}_{1}\right)\end{array}$ & $\begin{array}{c}\text { Green } \\
\text { Fodder } \\
\left(\mathrm{x}_{2}\right)\end{array}$ & $\begin{array}{c}\text { Concentrat } \\
\mathrm{e} \\
\left(\mathrm{x}_{3}\right)\end{array}$ & $\begin{array}{c}\text { Labour } \\
\left(\mathrm{x}_{4}\right)\end{array}$ & $\begin{array}{c}\text { Veterinar } \\
\mathrm{y} \\
\left(\mathrm{x}_{5}\right)\end{array}$ & $\mathrm{F}$ & $\mathrm{R}^{2}$ \\
\hline $\begin{array}{c}\text { Crossbre } \\
\text { d Cow }\end{array}$ & 70 & $\begin{array}{l}1.266 \\
(0.163)\end{array}$ & $\begin{array}{l}-0.062 \\
(0.157)\end{array}$ & $\begin{array}{l}0.499 * * \\
(0.237)\end{array}$ & $\begin{array}{c}0.184 \\
(0.192)\end{array}$ & $\begin{array}{l}0.146^{*} \\
(0.067)\end{array}$ & $\begin{array}{l}-0.008 \\
(0.057)\end{array}$ & 16.372 & 0.56 \\
\hline $\begin{array}{l}\text { Local } \\
\text { Cow }\end{array}$ & 40 & $\begin{array}{l}0.835 \\
(.183)\end{array}$ & $\begin{array}{c}0.013 \\
(0.098)\end{array}$ & $\begin{array}{l}0.622 * * \\
(0.162)\end{array}$ & $\begin{array}{l}0.182^{*} \\
(0.063)\end{array}$ & $\begin{array}{c}0.077 \\
(0.100)\end{array}$ & $\begin{array}{l}-0.012 \\
(0.112)\end{array}$ & 40.897 & 0.83 \\
\hline
\end{tabular}

Note: Figure is parentheses indicate standard error of estimate.

** Significant at $1 \%$ level of significance and * Significant at $5 \%$ level of significance 
Table.4 Marginal value productivity to factor cost ratio of milk for different categories of sample farms

\begin{tabular}{|l|c|c|c|}
\hline Particular & Green fodder & Concentrate & Labour \\
\hline Crossbred Cow & $4.45^{* *}$ & - & $2.32^{*}$ \\
\hline Local Cow & $6.73^{* *}$ & $2.96^{*}$ & - \\
\hline
\end{tabular}

** Significant at $1 \%$ level of significance and * Significant at $5 \%$ level of significance

Table.5 Technical efficiency rating for different categories of sample farms

\begin{tabular}{|c|c|c|c|c|}
\hline \multirow{2}{*}{$\begin{array}{c}\text { Technical efficiency } \\
\text { Rating (\%) }\end{array}$} & \multicolumn{5}{|c|}{ Farm Category } \\
\cline { 2 - 6 } & \multicolumn{2}{|c|}{ Crossbred Cow } & \multicolumn{2}{c|}{ Local Cow } \\
\cline { 2 - 5 } & No. of farms & $\%$ & No. of farms & $\%$ \\
\hline $\mathbf{8 0 - 8 2}$ & 10 & 16.66 & 11 & 27.5 \\
\hline $\mathbf{8 3 - 8 5}$ & 20 & 33.3 & 8 & 20.0 \\
\hline $\mathbf{8 6 - 8 8}$ & 23 & 38.33 & 17 & 42.5 \\
\hline $\mathbf{9 1 - 9 3}$ & 7 & 11.66 & 4 & 10.0 \\
\hline Total & 60 & 100 & 40 & 100 \\
\hline Mean & & 90.25 & & 89.90 \\
\hline
\end{tabular}

Table.6 Price spread of milk in Thoubal market through different marketing channel for crossbred cow

(Rs./liter)

\begin{tabular}{|l|c|c|c|c|c|c|}
\hline \multirow{2}{*}{ Particulars } & \multicolumn{2}{|c|}{ Channel-I } & \multicolumn{2}{c|}{ Channel-II } & \multicolumn{2}{c|}{ Channel-III } \\
\cline { 2 - 7 } & Rs. & $\%$ & Rs. & $\%$ & Rs. & $\%$ \\
\hline Producer selling price & 30 & 60 & 34 & 85 & 40 & 100 \\
\hline Net price received by the farmers & 30 & 60 & 34 & 85 & 39.48 & 98.7 \\
\hline Marketing cost & 3 & 6 & 1 & 2.50 & 0.52 & 1.3 \\
\hline Marketing margin & 17 & 34 & 5 & 12.5 & 0 & 0 \\
\hline Price paid by the consumer & 50 & 100 & 40 & 100 & 40 & 100 \\
\hline Producer price & 30 & 60 & 34 & 85 & 39.48 & 98.7 \\
\hline Price spread & 20 & 40 & 6 & 15 & 0.52 & 1.3 \\
\hline
\end{tabular}


Table.7 Price spread of milk in Thoubal market for local cow through channel-III

\begin{tabular}{|l|c|c|}
\hline \multirow{2}{*}{ Particulars } & \multicolumn{2}{|c|}{ Channel-III } \\
\cline { 2 - 3 } & Rs. & $\%$ \\
\hline Producer selling price & 50 & 100 \\
\hline Net price received by the farmers & 49.45 & 98.9 \\
\hline Marketing cost & 0.55 & 1.1 \\
\hline Marketing margin & 0 & 0 \\
\hline Price paid by the consumer & 50 & 100 \\
\hline Producer price & 49.45 & 98.9 \\
\hline Price spread & 0.55 & 1.1 \\
\hline
\end{tabular}

Table.8 Average producers share on consumer rupee for crossbred cow

\begin{tabular}{|c|c|c|c|}
\hline Channel & $\begin{array}{c}\text { Price received by the } \\
\text { farmers (Rs.) }\end{array}$ & Retail price(Rs.) & Producer share (\%) \\
\hline I & 30 & 50 & 60.00 \\
\hline II & 34 & 40 & 85.00 \\
\hline III & 39.48 & 40 & 98.70 \\
\hline
\end{tabular}

Table.9 Average producers shared on consumer rupee of local cow

(Rs. / litre)

\begin{tabular}{|c|c|c|c|} 
Channel & $\begin{array}{c}\text { Price received by the } \\
\text { farmer(Rs.) }\end{array}$ & Retail price(Rs.) & $\begin{array}{c}\text { Producer share } \\
(\mathbf{\%})\end{array}$ \\
\hline III & 49.45 & 50 & 98.77 \\
\hline
\end{tabular}

Table.10 Problems faced by farmers during milk production

\begin{tabular}{|l|c|c|c|c|}
\hline \multicolumn{1}{|c|}{ Problems } & $\begin{array}{c}\text { Crossbred Cow } \\
\text { (Avg. score) }\end{array}$ & Rank & $\begin{array}{c}\text { Local Cow } \\
\text { (Avg. score) }\end{array}$ & Rank \\
\hline $\begin{array}{l}\text { Low availability and high price of } \\
\text { concentrate }\end{array}$ & 72.45 & I & 70.35 & I \\
\hline Lack of availability of green fodder & 58.48 & II & 56.75 & II \\
\hline Lack of availability of dry fodder & 56.25 & III & 55.13 & III \\
\hline Lack of veterinary facilities & 55.20 & IV & 53.10 & IV \\
\hline Lack of training for scientific dairiying & 53.12 & V & 51.45 & V \\
\hline $\begin{array}{l}\text { Lack of awareness on animal health } \\
\text { care }\end{array}$ & 50.23 & VI & 49.42 & VI \\
\hline Repeat breeding & 48.56 & VII & 46.25 & VII \\
\hline Poor knowledge about balance feeding & 44.25 & VIII & 42.20 & VIII \\
\hline High cost of milch cow & 40.20 & IX & 38.10 & IX \\
\hline Incidence of reproductive disorder & 23.10 & X & 19.12 & X \\
\hline
\end{tabular}


Table.11 Problems faced by the farmers during marketing of milk

\begin{tabular}{|l|c|c|c|c|}
\hline \multicolumn{1}{|c|}{ Problems } & $\begin{array}{c}\text { Crossbred Cow } \\
\text { (Avg. score) }\end{array}$ & Rank & $\begin{array}{c}\text { Local Cow } \\
\text { (Avg. score) }\end{array}$ & Rank \\
\hline Low price of liquid milk & 75.46 & I & 65.75 & II \\
\hline $\begin{array}{l}\text { Delay in payment by } \\
\text { unorganized sector }\end{array}$ & 56.42 & II & 68.13 & I \\
\hline Lack of transport facilities & 52.31 & III & 30.10 & V \\
\hline Lack of market information & 37.28 & IV & 35.27 & IV \\
\hline Lack of cold storage facilities & 33.15 & V & 15.34 & VI \\
\hline $\begin{array}{l}\text { Lack of regulated market \& } \\
\text { milk cooperatives }\end{array}$ & 15.35 & VI & 36.21 & III \\
\hline
\end{tabular}

The above Table 10 shows the problems faced by the dairy farmers during the production of milk. The important problems faced by both farms of the dairy farmers were low availability and high price of concentrate feed in milk production. Farmers have to go far places for purchasing the concentrate feed which is turn increased their cost of production. Average scores of 72.45 for crossbred and 70.35 for local cow dairy farmers respectively felt that low availability of concentrate was usually one of the most important yield reducing factors. This problem was ranked first for both the crossbred and local cow farmers. About 58.48 average score of respondent farmers of crossbred and 56.75 of local cow of dairy farmers faced the shortage problem of green fodder which it ranked second for both the sample farmers. Nowadays the sample farmers also faced the problems of shortage of dry fodder also. Around 56.25 for crossbred and 55.13 average score for local cow sample farmers faced this problem. This was because of using threshing machine for paddy harvesting. Thus, the straws were cut into pieces so it was not suitable for long storage and such type of fodder was not like by the animals. Unavailability of veterinary facilities were also a major problems faced by many dairy farmers. It was found that 55.20 and 53.10 average score of crossbred and local cow farmers which they ranked in fourth position respectively. So they faced many problems during the vaccination, illness, and breeding of the cattle. However, average scores of parameters like lack of training for scientific dairying (53.12 and 51.45), lack awareness on animal health care (50.23 and 49.42), repeat breeding (48.56 and 46.25), poor knowledge about balanced feeding (44.25 and 42.20), high cost of mich cow $(40.20$ and 38.10) and incidence of reproductive disorder (23.10 and 1912) were found for crossbred cow and local cow respectively to be of less importance. These were also problems the farmers faced and also affect the milk productivity.

In the study of Table 11, average score of 75.46 and 65.75 of the sample dairy farmer reported that low price of milk. It is due to the perishable nature of this commodity and high concentration of cattle population and dairy farms in same areas. With the average scores of 56.42 and 68.13 for the crossbred and local cow dairy farmers faced the problems of delay in payment by unorganized sector. It affects on the timely requirement of feed and fodder for the cattle. Average score for crossbred cow was 52.31 and 30.10 for local cow of the respondents perceived the problems of lack of transportation facilities. Administration and cheaper rate of transportation were not readily available. Due to shortage of transportation facilities farmers 
were reluctant to go to town or city markets were price was high. Around 37.28 average score of crossbred cow and average score of 35.27 for local cow of the total sample farmers were lack of market information. So, sometimes the farmers were not getting reasonable price of their products. The next problem the farmers faced were lack of cold storage facilities and its average scores were 33.15 for crossbred and 15.34 for local cow. Milk as a perishable item they cannot store for a long period without proper storage facilities. So, the farmer leads to distress sale. About 15.35 average score of crossbred and 36.21 average score local cow farmers face the problem lack of regulated market and milk cooperatives. Most of the markets were supply near household and hotel only.

It is concluded, as compare to the local cow, the net return was very much more in crossbred cow. Thus, in the study area crossbred cow was found more profitable and economical. Keeping in view, local cows were less economically viable for milch due to the negative returns in this area.

Most of the resources were underutilized except for green fodder. Therefore, the resources should be used efficiently and effectively to increase the production of milk. There is further area for enhancing the milk yield by using more of labour and concentrate fed in case of crossbred. About 86.84 percent of milk total produced was marketed surplus and sold to different channels. The amount of milk consumed was higher in crossbred category but lower in local cow category. Thus, in order to increase the condition and profit of the farms, it be concluded from the present analysis that improvement of existing local breeds through cross breeding and introduction of scientific cultivation of green fodder, as green grasses were the only source of green fodder in the study area. The extension workers may also be suggested to make endeavour and motivate the farmers to acquire improved technology and proper management of different resources for increasing the dairy farmers' profit.

\section{Acknowledgement}

The authors acknowledge the contributions of O. Krishnadas Singh, Y. Chakrabarty Singh, Kh. Rishikanta Singh and N. Okendro Singh, College of Agriculture, Central Agricultural University, Imphal, Manipur (India) for their technical support and valuable contributions to the manuscript.

\section{References}

Bardhan, D. and Sharma, M.L. (2012). Economics of milk production in Kumaon region of Uttarakhand. Indian J. Dairy Sci. 65(5): 416-422.

Ghule, A., Verma, N. K., Cahuhan, A.K. and Sawale, P. (2012). An economic analysis of investment pattern, cost of milk production and profitability of commercial dairy farms in Maharashtra. Indian J. Dairy Sci. 65(4): 329-336.

Khoveio, L.L.M., Jain, D.K. and Chauhan, A.K. (2012). Economic of milk production and its constraint in Nagaland. Indian J. Dairy Sci., 65(6):520-526.

Mattigatti, R.M., Khan, K.S.S. and Suligavi, B.S. (1992). Marketing of milk in wardha district of Karnataka: An economic analysis. Indian J. Agri. Mkt., 6(1): 21-26.

Mondal, R.K., Sen, S. and Rayhan, S.J. (2010) A comparative economic analysis of local breed and cross breed milk cow in a selected area of Bangladesh. J. Sci. Foundation, 8(1\&2): 23-29.

Pandian, A.S.S., Shree, J.S., Raja, M.B. and Vetrivel, D. (2013). Efficiency of resources use in urban milk production 
in the state of Tamil Nadu, India. Inter. J. Vet. Sci., 2(4): 118-120.

Rangasamy, N. and Dhaka, J.P. (2008). Marketing efficiency of dairy products for co-operative and private dairy plants in Tamil Nadu. Agril. Econ. Res. Rev., 21(6): 235-242.

\section{How to cite this article:}

Krishnadas Singh, O., Y. Chakrabarty Singh, Kh. Rishikanta Singh and Okendro Singh, N. 2019. Economics of Milk Production and Marketing in Thoubal District of Manipur. Int.J.Curr.Microbiol.App.Sci. 8(06): 1397-1407. doi: https://doi.org/10.20546/ijcmas.2019.806.169 